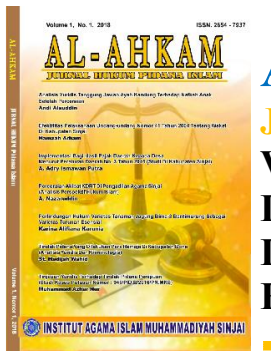

\title{
TINJAUAN YURIDIS TANGGUNG JAWAB PENGURUS Credit Union DALAM RAPAT ANGGOTA TAHUNAN
}

\author{
Muhammad Tahir', St. Hadijah Wahid ${ }^{2}$, Abunawas ${ }^{3}$ \\ ${ }^{1,3}$,Universitas Tanjungpura, Alamat : Jl. Prof. Dr. H. Hadari Nawawi, Bansir Laut, Kota Pontianak. \\ ${ }^{2}$ Institut Agama Islam Muhammadiyah Sinjai, Jln.Sultan Hasanuddin, Kab.Sinjai. \\ Email:m.tahir@hukum.untan.ac.id,Tlp:082208224585
}

\begin{abstract}
Abstrak
Penelitian ini bertujuan untuk pertama, mengidentifikasi kerugian yang dialami oleh sebuah Credit Union akibat kesalahan dan kelalaian pengurus didalam mengatur, mengurus dan mengelolah Credit Union. Kedua, mengidentifikasi bentuk pertanggungjawab pengurus kepada anggota ditinjau dari Undang-undang Nomor 25 Tahun 1992 tentang Perkoperasian. Metode penelitian yang digunakan merupakan jenis penelitian normatif empiris, yang bersifat deskriptif analitis. Menerapkan pendekatan studi literatur dan kepustakaan disertai wawancara dan pengamatan dilapangan. Kerugian yang dialami sebuah Credit Union merupakan bentuk penyalahgunaan wewenang yang diberikan oleh pengurus, karena sengaja dan lalai dalam melaksanakan tugas dan tanggungjawab yang diberikan oleh anggota. Penyebab kerugian tersebut disebabkan karena adanya penyalahgunaan didalam penggunaan dana lembaga yang diperuntukan untuk kepentingan dan keuntungan pribadi, dan meningkatnya pinjaman lalai yang tidak dapat tertangani, karena tidak memenuhi aspek kepatuhan dan kepatutan didalam pemberian dan penanganan pinjaman anggota sehingga sulit untuk melakukan eksekusi penyelesaian pinjaman tersebut, sebagaimana yang dialami oleh KSP. CU Muare Pesisir.
\end{abstract}

Kata Kunci: Pertanggungjawaban, Pengurus, Kerugian, Kesalahan dan Kelalaian.

1. Pendahuluan

Pengurus didalam Credit Union merupakan suatu elemen yang sangat penting, baik dan buruknya suatu Credit Union tergantung dari kecekatan dan kepiawaian dari seorang pengurus didalam mengelolah dan mengatur Credit Unionnya. Pengurus yang terpilih untuk memimpin Credit Union merupakan orang-orang pilihan yang dipilih didalam rapat anggota yang diadakan dalam Credit Union tersebut. Melihat tanggung jawab pengurus yang begitu luas yakni mengurus segala usaha, memutuskan dan melakukan segala tindakan dan upaya bagi kepentingan Credit Union sesuai dengan tanggung jawab yang diberikan kepadanya sebagaimana yang ditentukan didalam undang-undang, anggaran dasar maupun hal-hal lain yang telah ditentukan dalam rapat anggota, tentulah orang-orang yang dipilih tersebut tidak hanya memiliki pengetahuan dan pengalaman dalam tata kelola yang baik pada Credit Union, tetapi juga harus memiliki kejujuran dan mempunyai dedikasi yang tinggi untuk kemajuan Credit Union (Marjono, 2015 : 178).

Koperasi Simpan Pinjam Credit Union Muare Pesisir merupakan salah satu Credit Union yang ada dikalimantan barat yang berdiri tanggal 10 Mei 2003 di Desa Sungai Itik, Kecamatan Sungai Kakap, Kabupaten Kubu Raya yang saat ini telah memiliki 6 (enam) tempat pelayanan/kantor pelayanan yang tersebar dibeberapa kabupaten dan kota yang ada di Provinsi Kalimantan Barat, dengan keanggotaan sampai dengan akhir Desember 2020 sebanyak 2.882 orang yang terdiri dari 1.621 


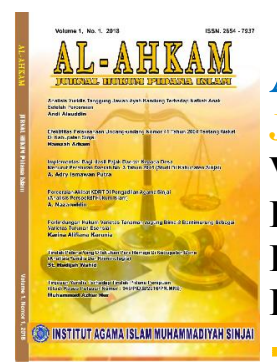

orang anggota laki-laki dan 1.261 anggota perempuan, yang merupakan kumpulan orang yang memiliki latar belakang berupa karyawan perusahaan, pedagang lapak pasar, pedagang kaki lima, pedagang asongan, ibu rumah tangga, pegawai negeri sipil, nelayan, petani, buruh, mahasiswa, pelajar serta anggota luar biasa lainnya, dengan total aset yang dimiliki saat ini sebesar Rp. 37.075.107.682,- (tiga puluh tujuh milyar tujuh puluh lima juta seratus tujuh ribu enam ratus delapan puluh dua rupiah).

Credit Union merupakan sebuah wadah yang terdiri dari kumpulan pribadi (manusia/orang) yang merupakan pemilik modal serta pemegang kekuasaan tertinggi didalam kelembagaan tersebut, yang memiliki tujuan dan pandangan yang sama, tanpa adanya paksaan. Dengan kata lain Credit Union adalah sarana anggota untuk menabung dengan sistem kepercayaan, yang artinya masing-masing orang tersebut saling percaya mempercayai, saling bertanggungjawab dalam memanfaatkan tabungan dalam bentuk pinjaman sesama anggota untuk kemajuan bersama yang biasa dikenal dengan istilah "The Credit Union provides vehicle; the members use it to arrive at their financial destination” (Monaldus, dkk. 2012).

Dengan adanya modal yang besar diharapkan dapat menghasilkan surplus hasil usaha yang besar, berkeadilan, berkelanjutan dan mensejahterahkan seluruh anggota (Martono. 2016 : 1-3). Namun senyatanya pengurus Credit Union tidak dapat menjalankan sepenuhnya tanggungjawab yang diberikan dalam rapat anggota kepadanya secara amanah dan bijaksana, sehingga segala kebijakan pengurus maupun strategic planning yang akan diambil malah akan merugikan anggota dan berdampak pada keberlangsung dari Credit Union itu sendiri yang selalu mengalami kerugian disetiap tahunnya dengan nilai sisa hasil usaha yang selalu minus (rugi). Ada beberapa faktor penyebab meruginya Credit Union yang disebabkan oleh tindakan tidak terpuji dari pengurus, pengawas dan manajemen yang dengan sengaja menggelapkan dan menggunakan uang simpanan anggota untuk kepentingan dan keuntungan pribadi serta tingginya angka kredit lalai yang dialami Credit Union yang tidak memenuhi aspek legalitas pemberian pinjaman maupun dalam penyelesaiannya.

Menitik beratkan dari hal tersebut, maka dianggap perlu adanya tinjauan yuridis bentuk tanggungjawab pengurus didalam mengatur, mengurus dan mengelolah Credit Union sebagaimana yang dimaksud didalam Pasal 34 Undangundang No. 25 Tahun 1992 Tentang Perkoperasian.

\section{Metode}

Jenis penelitian yang digunakan dalam penelitian ini yaitu menggunakan jenis penelitian normatif empiris. Jenis penelitian hukum normatif emperis merupakan suatu bentuk penelitian hukum yang mengkaji terkait pemberlakuan terhadap ketentuan-ketentuan hukum normatif secara in action pada suatu peristiwa tertentu yang terjadi di masyarakat (Abdulkadir Muhammad, 2004 : 134). Pendekatan penelitian hukum normatif empiris dengan cara menelaah baku utama berupa data sekunder yang bersifat teoritis menyangkut asas-asas hukum, konsepsi hukum, pandangan, dan doktrin-doktrin hukum, segala peraturan dan sistem hukum, dengan cara memperlajari perundangan-undangan yang ditunjang oleh beberapa buku 


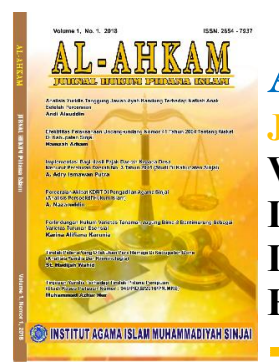

ataupun dokumen lain yang relevan (Soerjono Soekanto. $2006: 2$ ), yang berkaitan dengan tanggung jawab pengurus kepada anggota terhadap kerugian yang dialami oleh Credit Union akibat kesalahan dan kelalaian didalam pelaksanaan tugas dan penyalahgunaan wewenang yang dilakukan oleh pengurus.

Adapun sumber data yang digunakan adalah data primer yang diperoleh dari wawancara dan pengamatan langsung dilapangan dan data sekunder berupa Undang-undang Nomor 25 Tahun 1992 tentang Perkoperasian, Anggaran Dasar dan Anggaran Rumah Tangga KSP. CU Muare Pesisir, serta Manual Operasional dan Manual Prosedur yang dimiliki KSP. CU Muare Pesisir, yang didukung dengan beberapa buku-buku, leteratur, hasil penelitian hukum, Kamus Bahasa Indonesia, Kamus Hukum, dan Ensiklopedia yang dipergunakan untuk membantu dalam menganalisa dan memberi penjelasan yang berhubungan dengan permasalahan yang diteliti. Kemudian data yang diperoleh dikembangkan dan dianalisa secara deskriptif analitis yang menggambarkan secara menyeluruh obyek yang diteliti secara terukur dan sistematis.

3. Hasil dan Pembahasan

a. Aspek Yuridis Tanggungjawab dan Kewenangan berupa Mandat yang diberikan kepada Pengurus dalam Credit Union

Tanggungjawab dan kewenangan merupakan hal yang tidak dapat dipisah dalam pengelolahan suatu lembaga atau organisasi yang diberikan kepada sesorang dengan mandat untuk dapat dilaksanakan dengan sebaik-baiknya, didalam mandat tersebut terdapat suatu kewenangan atau batasan yang menjadi penentu seseorang untuk dapat melakukan suatu perbuatan atau tidak melakukan suatu perbuatan yakni berupa kewenangan untuk berbuat dan kewenangan untuk bertindak untuk dan atas nama organisasi atau lembaga yang dipimpinnya. Untuk menyatakan seseorang memiliki kewenagan atau tidak, dapat dilihat dari mana sumber kewenangan itu diperoleh, maka terdapat 3 (tiga) kategori untuk menyatakan keabsahan suatu kewenangan yakni kewenangan artibutif, kewenangan delegatif dan kewenangan mandat (Nur Basuki Winarno. 2008 : 70-75). Begitupula didalam konsep tanggungjawab dan kewenangan pengurus dalam Credit Union, untuk mengelolah dan mengurus keberlangsungan lembaga sesuai dengan mandat yang diberikan oleh rapat anggota baik itu yang tertuang didalam anggaran dasar maupun didalam peraturan perundang-undangan.

Dalam mengelolah segala usaha Credit Union, pengurus juga diberi wewenang untuk dapat mengangkat seseorang atau lebih yang menjadi perpanjangan-tangan pengurus didalam mengelolah dan menjalankan segala aktifitas sehari-hari yang ada di CU tersebut yang biasa diistilahkan dengan "staf manajemen" yang terdiri dari General Manager atau Manager serta staf pelaksana lainnya sesuai dengan kebutuhan yang ada. Pada prinsipnya staf manajemen yang telah ditunjuk tidak mengurangi tanggungjawab pengurus yang ada, hubungan antara staf manajemen dengan pengurus merupakan hubungan kerja antara pemberi kerja dan penerima kerja atas dasar perjanjian kerja (perikatan), dengan adanya kewenangan yang diberikan pengurus untuk mengangkat staf manajemen diharapkan dalam mengelolah Credit Union dapat 


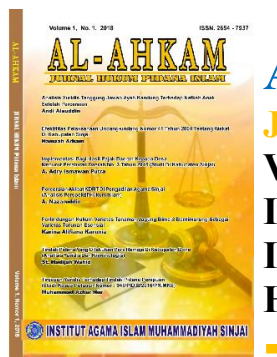

dijalankan secara profesionalisme yang semata-mata untuk kepentingan, kemanfaatan dan keberlajutan Credit Union beserta seluruh anggotanya. Dengan demikian sesuai dengan kepentingan pengelolahan Credit Union pengurus tidak lagi sendiri melaksanakan wewenang dan mandat yang telah diberikan dari rapat anggota kepadanya, karena kewenangan dan pengelolahan dan pengurusan Credit Union telah dilimpahkan kepada staf manajemen. Dalam hal ini pengurus beralih menjadi mengawasi pelaksanaan wewenangan dan mandat yang telah dilimpahkan kepada staf manajemen, kemudian staf manajemen tersebut bertanggungjawab sepenuhnya kepada pengurus, pelimpahan kewenangan tersebut pada dasarnya tidak mengurangi tanggungjawab pengurus kepada rapat anggota yang memiliki kekuasaan tertinggi berhak meminta keterangan, pertanggungjawaban pengurus dan mengesahkan laporan pertanggungjawaban pengurus setiap tahunnya.

Tidak hanya wewenang yang diberikan kepada pengurus didalam mengelolah keberlangsungan jalannya suatu Credit Union, akan tetapi didalam anggaran dasar dan anggaran rumah tangga yang telah diatur dan diputus bersama didalam rapat anggota juga mengatur hak dan kewajiban pengurus dalam Credit Union. Besarnya tanggungjawab yang diemban pengurus Credit Union yang tidak hanya sebatas mengelolah, mengurus kelangsungan dan eksistensi dari suatu Credit Union. Pengurus baik secara bersama-sama maupun sendiri-sendiri menanggung segala kerugian yang diderita oleh Credit Union, atas tindakan yang dilakukannya baik dengan sengaja atau kealpaan yang dipertanggungjawabkan secara perdata maupun pidana.

b. Framework Tata Kelola Yang Baik Pada Credit Union

Credit Union merupakan suatu lembaga keuangan yang dijalankan secara demokratis dengan adanya pembagian hasil (profit sharing), dan menawarkan beberapa produk simpanan dan pinjaman yang berbunga rendah kepada setiap anggotanya dengan tujuan untuk mendorong kesejahteraan anggota terutama saling membantu terkait permasalahan keuangan. Keanggotaan yang sukarela (voluntarily) merupakan ciri utama dari suatu Credit Union, sehingga memunculkan rasa saling memiliki dan saling percaya sesama anggota, yang menempatkan para anggota sebagai pemilik dari Credit Union itu sendiri, dengan kata lain dari, oleh dan untuk anggota sesuai dengan prinsip-prinsip utama Credit Union internasional didalam world council of Credit Unions (WOCCU) yakni kesetaraan, keadilan dan menolong diri sendiri dalam kebersamaan (mutual self-helf) (Monaldus, dkk. 2012 : 31). Untuk menerapkan prinsip-prinsip tersebut setiap Credit Union harus memperhatikan 3 (tiga) elemen utama yang biasa dikenal dengan istilah "operating prinsiples of Credit Union" yakni sebagai berikut :

1) Struktur yang demokratis

Keanggotaan yang bersifat terbuka dan sukarela terhadap semua orang tanpa adanya diskriminasi, artinya setiap orang tanpa memandang status, latar belakang, suku, agama, politik dan bangsa bisa menjadi anggota Credit Union tanpa ada paksaan dari pihak manapun. Setiap keanggotaan Credit Union berada dalam ikatan pemersatu (common bond) yang dapat 


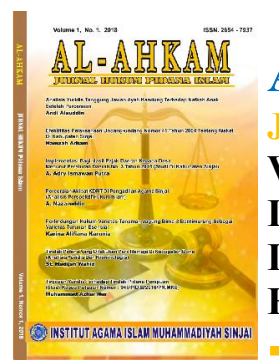

memanfaatkan pelayanan dari Credit Union dan bersedia memikul tanggungjawab bersama (Monaldus, dkk. 2012 : 31), para anggota memiliki hak yang sama untuk memilih (satu anggota satu suara) dan berpartisipasi didalam membuat keputusan dan kebijakan untuk kemajuan Credit Union, tanpa memperhatikan jumlah simpanan atau tabungan atau volume bisnis sesuai dengan kerangka hukum dan peraturan perundangundangan. Credit Union yang baik adalah melayani anggota dan diawasi oleh anggota.

2) Pelayanan kepada anggota

Hal utama yang menjadi perhatian setiap Credit Union adalah membangun kekuatan keuangan dengan ketersedian dana yang cukup, sehingga mendorong setiap anggota untuk menerapkan pola hidup hemat untuk menabung ke Credit Union yang dapat memperkuat keuangan CU itu sendiri. Pelayanan yang optimal diharapkan dapat meningkatkan kesejahteraan ekonomi dan sosial semua anggota, surplus (pendapat bersih) yang diperoleh dari kegiatan usaha CU setelah menutupi biaya modal, biaya operasional, provisi pinjaman lalai, dan untuk memenuhi ketentuan dan persyaratan dana cadangan, menjadi milik anggota dan bermanfaat bagi anggota sehingga tidak seorangpun anggota yang merasa dirugikan, karena surplus ini didistibusikan kepada semua anggota sebanding dengan jumlah jasa yang diberikannya kepada CU.

3) Tujuan Sosial

Karakter sosial ekonomi Credit Union pada prinsipnya memberikan pendidikan secara terus menerus kepada anggota, pengurus, pengawas dan staf manajemen maupun kepada masyarakat pada umumnya untuk dapat menerapkan pola hidup hemat (thrift) dan menggunakan pinjaman secara bijaksana, pemahaman terhadap hak dan tanggungjawab anggota berdasarkan prinsip tolong menolong, menolong diri sendiri dalam kebersamaan (mutual self-help). selain itu dalam praktek pengaturan koperasi secara aktif dapat melakukan kerjasama antar CU lain, koperasi dan lembaga lain baik ditingkat lokal, nasional maupun internasional guna memberikan pelayanan terbaik kepada anggota dan masyarakat.

Terlaksananya prinsip-prinsip Credit Union (operating prinsiples of Credit Union) maka akan terwujudnya misi dari Credit Union itu sendiri, menjadikan Credit Union sebagai kendaraan anggota untuk mencapai tujuan keuangan masing-masing (The Credit Union provides vehicle; the members use it to arrive at their financial destination), dan untuk menjalankan kendaraan tersebut maka diperlukan seorang pengemudi yang handal agar dapat mengantar penumpangnya sesuai dengan tujuan yang diharapkan, dalam hal ini kedudukan dan kapasitas pengurus sebagai wali dari anggota memiliki peran yang sangat penting didalam keberlangsungan suatu Credit Union, berhasil tidaknya suatu Credit Union tergantung pada manusia yang mengelolahnya dan sistem tata kelola yang baik dalam mendukung hal tersebut (no Credit Union success without good people and good system) baik itu dari proses mempersiapkan kader pengurus, penjaringan pengurus, sampai dengan 


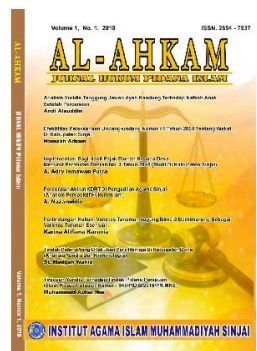

Al-Ahkam

Jurnall Hukum Pidana Islam

Volume 3, No. 1, 2021

ISSN (print) : 2654-7937

ISSN (online) : 2715-0313

Homepage $\quad$ : http://journal.iaimsinjai.ac.id/index.php/al-ahkam/index

pengangkatan dan penetapan sebagai seorang pengurus Credit Union, hal ini mengacu kepada ketentuan governance framework for Credit Union yakni pengangkatan seorang pengurus tidak dapat dilakukan apabila tidak melalui masa seleksi yang baik dan orentasi yang memadai serta hanya bisa menjabat selama 2 (dua) masa jabatan secara terus menerus (Sukoco Irianto. 2017 : 50).

Tabel 1. Good People dan Good System

\begin{tabular}{|c|c|}
\hline Good People & Good System \\
\hline $\begin{array}{ll}\text { a. } & \text { Para Anggota } \\
\text { b. } & \text { Dewan Pengurus } \\
\text { c. } & \text { Dewan Pengawas } \\
\text { d. } & \text { Dewan Penasehat } \\
\text { e. } & \text { Staf Manajemen (General Manager, } \\
\text { f. } & \text { Kelomper, Kepala Bagian dan Staf) }\end{array}$ & $\begin{array}{ll}\text { a. } & \text { Berbadan hukum dan memiliki } \\
& \text { segala bentuk perijinan operasional } \\
& \text { Credit Union } \\
\text { b. } & \text { Memiliki angggaran dasar dan } \\
& \text { anggaran rumah tangga } \\
\text { c. } & \text { Memiliki manual operasional } \\
\text { d. } & \text { Memiliki manual prosedur } \\
\text { e. } & \text { Struktur organisasi } \\
\text { f. } & \text { Produk dan layanan } \\
\text { g. } & \text { Siklus keuangan dan pelaporan yang } \\
\text { h. } & \text { baik } \\
& \text { Memiliki sarana pendukung lainnya } \\
& \text { (program aplikasi, PEARLS, SAK- } \\
\text { ETAP dan lain-lain). }\end{array}$ \\
\hline \multicolumn{2}{|c|}{$\begin{array}{l}\text { Perlu adanya kolaborasi yang baik antara people and system didalam tata kelola yang } \\
\text { baik suatu Credit Union, kualitas dan kapasitas people tercermin dari attitude, skills, } \\
\text { knowledge, character, passion, honesty dan lainnya melalui pendidikan dan pelatihan. } \\
\text { Keseluruhan kebijakan, produk dan layanan yang terdapat di CU tersebut secara terus } \\
\text { menerus disosialisasikan kepada seluruh komponen CU, serta penyesuaian kebijakan dan } \\
\text { program aplikasi sesuai dengan perkembangan dan kebutuhan suatu CU. }\end{array}$} \\
\hline
\end{tabular}

Sumber : Wawancara Ketua Pengurus KSP. CU Muare Pesisir

Tabel 2. Prinsip-Prinsip Tata Kelola Yang Baik Pada Credit Union

\begin{tabular}{|c|c|c|}
\hline \multicolumn{3}{|c|}{ Prinsip-Prinsip Tata Kelola Yang Baik } \\
\hline \multirow{2}{*}{$\begin{array}{l}\text { Tata Kelola } \\
\text { Eksternal }\end{array}$} & Transparansi & \multirow{2}{*}{$\begin{array}{l}\text { - Adanya keterbukaan diharapkan } \\
\text { memunculkan saling kepercayaan } \\
\text { antara pengurus, pengawas, } \\
\text { manajemen, anggota serta } \\
\text { stakeholder lainnya. Dimulai dari } \\
\text { komunikasi yang baik, laporan } \\
\text { keuangan dan standar akuntasi } \\
\text { yang jelas dan akuntabel. } \\
\text { - Adanya standar kepatuhan hukum } \\
\text { baik dari adanya akta pendirian, } \\
\text { anggaran dasar dan anggaran } \\
\text { rumah tangga, serta kepastian akan } \\
\text { penerapan kebijakan. }\end{array}$} \\
\hline & Kepatuhan Hukum & \\
\hline \multirow[b]{4}{*}{ Tata Kelola Internal } & Struktur Organisasi & \multirow{4}{*}{$\begin{array}{l}\text { - Adanya batasan kewenangan } \\
\text { didalam lembaga CU tersebut, } \\
\text { antara anggota, pengurus, } \\
\text { pengawas, penasehat, manajemen } \\
\text { dan kelompok inti, yang dapat } \\
\text { dijalankan secara terus menerus } \\
\text { dan berkesinambungan serta dapat } \\
\text { dipertanggungjawabkan. }\end{array}$} \\
\hline & Kontinuitas & \\
\hline & Keseimbangan & \\
\hline & Akuntabilitas & \\
\hline
\end{tabular}




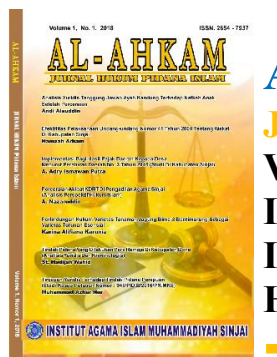

Al-Ahkam

Jurnal Hukum Pidana Islam

Volume 3, No. 1, 2021

ISSN (print) : 2654-7937

ISSN (online) : 2715-0313

Homepage : http://journal.iaimsinjai.ac.id/index.php/al-ahkam/index

\begin{tabular}{|c|c|c|}
\hline \multirow[b]{3}{*}{ Tata Kelola Individu } & Integeritas & \multirow[b]{3}{*}{$\begin{array}{l}\text { - } \text { Sikap, kemampuan dan kapasitas } \\
\text { yang dimiliki dalam pengelolahan } \\
\text { Credit Union harus memiliki } \\
\text { komitmen untuk memajukan } \\
\text { Credit Union yang } \\
\text { bertanggungjawab, mampu } \\
\text { menjalankan dan mengelolah } \\
\text { Credit Union sesuai dengan arah } \\
\text { kebijakan yang ada serta memiliki } \\
\text { kemampuan dan pengembangan } \\
\text { diri sesuai dengan keperluan CU } \\
\text { tersebut. }\end{array}$} \\
\hline & Kompetensi & \\
\hline & Komitmen & \\
\hline
\end{tabular}

Sumber : Wawancara General Manajer KSP. CU Muare Pesisir

c. Bentuk Pertanggungjawaban Pengurus dalam Rapat Anggota Tahunan KSP. CU

Muare Pesisir

1) Pertanggungjawaban Terhadap Keorganisasian

Sebuah Credit Union yang baik sebagai suatu badan usaha kumpulan orang yang kegiatan-kegiatan usahanya dengan tujuan utama adalah melayani segala kepentingan anggota, yang dilaksanakan secara merata, adil dan bijaksana. Perwujudan pelayanan tersebut tentunya perlu seperangkat organ pelaksana yang memiliki tugas dan fungsi yang didukung dengan kewenangan yang dimiliki untuk menopang tugas dan fungsinya tersebut, yakni dengan memiliki sturuktur organisasi yang memadai sesuai dengan kebutuhan dan perkembangan guna terlaksananya pelayanan yang maksimal kepada semua anggota. Pentingnya sebuah struktur organisasi didalam suatu Credit Union memberikan suatu batasan kewenangan seorang didalam jabatannya melaksanakan fungsi, tugas dan pertanggungjawaban pada setiap tingkatan-tingakatan organ pelaksana didalam tubuh struktur organisasi tersebut,

Pertanggunjawaban pengurus didalam tata laksana keorganisasian tidak hanya mencakup terpenuhinya organ pelaksana pendukung di setiap unit kerja, tetapi yang harus menjadi perhatian adalah sejauhmana produktivitas sumber daya manusia disetiap organ pelaksana disetiap unit kerja tersebut dalam menyusun, mengatur, dan mengelompokan macam-macam pekerjaan yang akan dikerjakan untuk mencapai suatu tujuan bersama yang dapat dipertanggungjawabkan seusai dengan jabatan dan kewenangan yang dimilikinya. Dengan adanya tata organisasi yang baik diharapkan tujuan dan rencana-rencana kerja yang telah direncanakan sedemikian rupa dan telah diputus secara bersama dalam program kerja tahunan dapat berjalan sesuai dengan apa yang telah ditentukan, dan adanya evaluasi secara berkala untuk mengetahui sejauh mana tercapainya target-target didalam program kerja tersebut serta untuk mengatasi sedini mungkin kendala-kendala yang dihadapi dengan memperhatikan aspek kepatuhan, dan kepatutan didalam tata kelola yang baik suatu Credit Union 


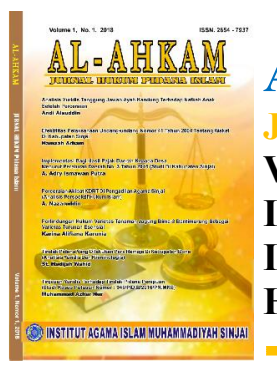

2) Pertanggungjawaban Terhadap Pertumbuhan dan Perkembangan Anggota Kemajuan suatu Credit Union tidak terlepas dari eksistensi keberadaan anggotanya, anggota yang banyak belum tentu dapat memberikan kontribusi yang baik bagi keberlangsungan sebuah Credit Union, terutama bagi CU-CU yang baru berdiri agar dapat bertahan dan bersaing dengan CU-CU lain yang usianya lebih tua, hal utama yang harus menjadi perhatian adalah pertumbuhan dan perkembangan anggota dari tahun ke tahun. Jika beranjak dari misi awal berdirinya lembaga yang bernama Credit Union adalah membantu orang miskin untuk dapat keluar dari situasi kemiskinannya dengan cara bekerja sama dan saling percaya, mereka menabung sebagian uangnya untuk menghimpun modal bersama, yang kemudian mereka pinjamkan sesama mereka yang membutuhkan dengan tujuan agar keluar dari permasalahan keuangannya dan bisa produktif menghasilkan uang agar dapat ditabungkan kembali untuk memperbesar modal bersama mereka.

Pentingnya membangun solidaritas sesama anggota yang saling percaya merupakan salah satu tanggungjawab yang diemban oleh pengurus, yang tidak hanya mencerdaskan anggotanya untuk dapat mengelolah keuangan mereka secara finansial tetapi juga secara sosial mau saling membantu sama lain untuk mencapai tujuan bersama meningkatkan ekonomi anggota. Hal ini hanya dapat dilakukan pengurus dengan cara memberikan pendidikan dan pelatihan kepada anggota secara berkala dan berkelanjutan. Dalam makna hakiki keberhasilan suatu Credit Union didalam mensejahterakan anggotanya, akan menjadi magnet untuk mempengaruhi orang lain yang tadinya bukan anggota, bisa menjadi percaya dan mau bergabung bersama. Melalui pendidikan anggota dapat memahami konsep dasar didalam berCredit Union dan melalui pendidikan pula anggota dapat mengontrol keberlangsungan Credit Union tersebut serta melalui pendidikan dapat membangun ekonomi anggota. Hal ini lah yang menjadi pondasi awal untuk menjaga agar dapat bertahan dan tumbuh berkembang (sustainable).yang biasa dikenal dengan trilogi Credit Union dengan tiga pilarnya yakni pendidikan, setiakawan (solidaritas) dan swadaya.

Tugas utama dari seorang pengurus didalam pertumbuhan dan perkembangan anggota adalah dengan memastikan dapat meningkatkan kualitas hidup anggota dengan melaksanakan pendidikan agar anggota menjadi cerdas tidak hanya keluar dari permasalahan keuangan yang mereka hadapi tetapi mampu membuat perencanaan keuangan yang benar, menjadikan pinjaman yang diberikan sebagai alat untuk menciptkaan kesejahteraan dan meningkatkan kualitas hidup, pemberdayaan dan pengembangan tumbuh kembang usaha anggota, serta dengan membiasakan agar anggota mau terus menabung secara berkelanjutan.

3) Tanggungjawab Pengurus terhadap Keuangan Credit Union

Indikator salah satu keberhasilan pengurus didalam mengelolah sebuah Credit Union adalah dapat mengatur keuangan secara baik dan benar, the become a safe and sound financial institution that above all else has earned the trush of the community in which it operates yakni menjadikan Credit 


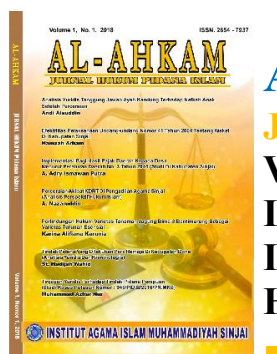

Union sebagai lembaga keuangan yang aman dan sehat sehingga memperoleh kepercayaan masyarakat pada umumnya dan kepercayaan anggota pada khususnya disemua wilayah pelayanan dimana CU itu berada (Sukoco Irianto. 2017 : 20). Sehat tidaknya dan maju-mundurnya suatu Credit Union pada umumnya dapat ditentukan melalui posisi keuangan dalam periode tertentu (perbulan, tiga bulan, enam bulan dan pertahun) yang mengambarkan suatu prestasi kerja yang dilakukan oleh pengelolah, dibuat didalam laporan keuangan (financial statement) menggunakan Standar Akutansi Keuangan Entitas Tanpa Akutansi Publik (SAK ETAP).

Laporan keuangan (financial statement) merupakan hasil pencatatan yang dilakukan oleh pengurus yangg berkaitan dengan seluruh transaksi keuangan $\mathrm{CU}$, dibuat secara terstruktur dan sistematis agar anggota dapat mempelajari dan memahami dengan muda isi dari laporan keuangan tersebut, didalam laporan keuangan pada prinsipnya paling tidak memuat beberapa komponen, yakni perkembangan umum lembaga antara target, realisasi dan pencapaian selama tahun berjalan, Neraca (balance sheet) yang terdiri dari gambaran umum aset yang dimiliki, jumlah pinjaman yang beredar (liabelities) dan modal (owner's equity) yang dianalisa menggunakan sistem analisis PEARLS sesuai dengan standar Credit Union Internasional yang dikeluarkan oleh World Council Of Credit Unions (WOCCU) yang merupakan suatu alat analisis yang digunakan untuk menilai tingkat kesehatan sebuah Credit Union dengan menggunakan beberapa indikator penilaian, yakni (Nicodemus Simu : 2017) :
a) Protection (Perlindungan)
b) Effective Financial Struktur (Struktur Keuangan Efektif)
c) Asset Quality (Kualitas Aset),
d) Rates of Return and Costs (Tingkat Pendapatan dan Biaya),
e) Liquidity (Dana Likuid),
f) Signs of Growth (Tanda-tanda Pertumbuhan),

Tabel 3 : Analisis PEARLS Laporan Keuangan KSP. CU Muare Pesisir

\begin{tabular}{|c|c|c|c|c|c|}
\hline Analisis Pearls & & Indikator & Rasio & Ideal & Ket. \\
\hline \multirow{2}{*}{$\begin{array}{c}\mathbf{P}=\text { Protection } \\
\text { (Perlindungan) }\end{array}$} & $\mathrm{P} 1$ & $\begin{array}{l}\text { Mengukur kemampuan } \\
\text { CU menyediakan dana } \\
\text { cadangan resiko atas } \\
\text { piutang lalai } \geq 12 \text { bulan }\end{array}$ & $42,12 \%$ & $100 \%$ & $\begin{array}{l}\text { Tidak } \\
\text { Ideal }\end{array}$ \\
\hline & $\mathrm{P} 2$ & $\begin{array}{l}\text { Mengukur kemampuan } \\
\text { CU menyediakan dana } \\
\text { cadangan resiko atas } \\
\text { piutang lalai } \leq 12 \text { bulan }\end{array}$ & $78,42 \%$ & $35 \%$ & $\begin{array}{l}\text { Tidak } \\
\text { Ideal }\end{array}$ \\
\hline \multirow{2}{*}{$\begin{array}{c}\mathbf{E}=\text { Effective } \\
\text { Financial } \\
\text { Stucture } \\
\text { (Struktur } \\
\text { keuangan yang } \\
\text { efektif) }\end{array}$} & E1 & $\begin{array}{l}\text { Mengukur persentase } \\
\text { total aset yang } \\
\text { diinvestasikan dalam } \\
\text { piutang }\end{array}$ & $56,31 \%$ & $\begin{array}{c}70-80 \\
\%\end{array}$ & $\begin{array}{l}\text { Tidak } \\
\text { Ideal }\end{array}$ \\
\hline & E5 & $\begin{array}{l}\text { Mengukur persentase } \\
\text { total asset yang didanai } \\
\text { dari simapanan non- } \\
\text { saham }\end{array}$ & $74,44 \%$ & $\begin{array}{c}70-80 \\
\%\end{array}$ & Ideal \\
\hline
\end{tabular}




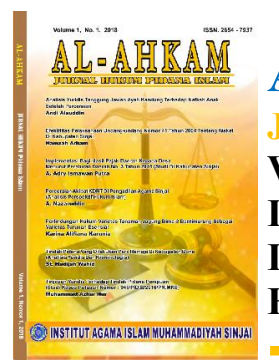

Volume 3, No. 1, 2021

ISSN (print) : 2654-7937

ISSN (online) : 2715-0313

Homepage : http://journal.iaimsinjai.ac.id/index.php/al-ahkam/index

\begin{tabular}{|c|c|c|c|c|c|}
\hline & E6 & $\begin{array}{l}\text { Mengukur persentase } \\
\text { total asset yang didanai } \\
\text { dari pinjaman pihak } \\
\text { ketiga (termasuk di } \\
\text { Puskopbit BKCU } \\
\text { Kalimantan) }\end{array}$ & $3,31 \%$ & $\leq 5 \%$ & Ideal \\
\hline & E9 & $\begin{array}{l}\text { Mengukur level nyata } \\
\text { dari modal lembaga } \\
\text { setelah mengeluarkan } \\
\text { penyisihan (DCR untuk } \\
\text { menutupi P1 \& P2) }\end{array}$ & $-4,68 \%$ & $\geq 10 \%$ & $\begin{array}{l}\text { Tidak } \\
\text { Ideal }\end{array}$ \\
\hline \multirow{2}{*}{$\begin{array}{l}\text { A=Asset } \\
\text { Quality } \\
\text { (Kualitas } \\
\text { Asset) }\end{array}$} & A1 & $\begin{array}{l}\text { Mengukur persentase } \\
\text { total kelalaian piutang } \\
\text { terhadap total piutang }\end{array}$ & $26,32 \%$ & $\leq 5 \%$ & $\begin{array}{l}\text { Tidak } \\
\text { Ideal }\end{array}$ \\
\hline & $\mathrm{A} 2$ & $\begin{array}{l}\text { Mengukur total asset } \\
\text { yang tidak menghasilkan } \\
\text { income }\end{array}$ & $22,17 \%$ & $\leq 5 \%$ & $\begin{array}{l}\text { Tidak } \\
\text { Ideal }\end{array}$ \\
\hline \multirow{2}{*}{$\begin{array}{c}\text { R=Rates Of } \\
\text { Return On } \\
\text { Costs (Nilai } \\
\text { Pengembalian } \\
\text { Atas Biaya) }\end{array}$} & R7 & $\begin{array}{l}\text { Mengukur persentase } \\
\text { pengembalian biaya atas } \\
\text { simpanan saham }\end{array}$ & $0 \%$ & 3,75 & Ideal \\
\hline & R9 & $\begin{array}{l}\text { Mengukur persentase } \\
\text { beban mengelola semua } \\
\text { asset }\end{array}$ & $8,81 \%$ & $5 \%$ & $\begin{array}{l}\text { Tidak } \\
\text { Ideal }\end{array}$ \\
\hline $\begin{array}{c}\mathbf{L}=\text { Liquidity } \\
\text { (Likuiditas) }\end{array}$ & L1 & $\begin{array}{l}\text { Mengukur persentase } \\
\text { cadangan likuit untuk } \\
\text { memenuhi permintaan } \\
\text { penarikan setelah } \\
\text { membayar semua } \\
\text { kewajiban }<30 \text { hari }\end{array}$ & $20 \%$ & $\begin{array}{c}15-20 \\
\%\end{array}$ & $\begin{array}{l}\text { Tidak } \\
\text { Ideal }\end{array}$ \\
\hline \multirow{2}{*}{$\begin{array}{c}\text { S=Signs Of } \\
\text { Growth } \\
\text { (Tanda-tanda } \\
\text { pertumbuhan) } \\
\text { Penetrasi } \\
\text { Pasar 35-50\% } \\
\end{array}$} & $\mathrm{S} 10$ & $\begin{array}{l}\text { Mengukur persentase } \\
\text { pertumbuhan anggota dari } \\
\text { tahun ke tahun }\end{array}$ & $-6,73 \%$ & $>12 \%$ & $\begin{array}{l}\text { Tidak } \\
\text { Ideal }\end{array}$ \\
\hline & S11 & $\begin{array}{l}\text { Mengukur persentase } \\
\text { pertumbuhan total asset } \\
\text { dari tahun ke tahun }\end{array}$ & $10,70 \%$ & $\begin{array}{l}10 \%+ \\
\text { Laju } \\
\text { Inflasi }\end{array}$ & \\
\hline
\end{tabular}

Sumber : Laporan Tahun Buku 2020 KSP. CU Muare Pesisir

Dari data analisis PEARLS laporan keuangan KSP. CU Muare Pesisir diatas, menunjukan bahwa kondisi keuangan lembaga saat ini dalam keadaan yang sangat memperhatikan atau bisa dikatakan kondisi KSP. CU Muare Pesisir sedang tidak sehat, ini dapat dilihat dari sebagian besar indikator didalam penilaian PEARLS menunjukan kondisi yang tidak ideal. adapun penyebabnya adalah sebagai berikut :

a) Besarnya jumlah pinjaman lalai yang beredar dan sulit tertagih, baik itu dibawah 12 bulan atau diatas 12 bulan.

b) Masih minimnya ketersediaan dana cadangan yang dimiliki.

c) Rendahnya minat anggota untuk meminjam, sehingga mengurangi pendapatan CU dari bunga pinjaman.

d) Anggota hanya menyimpan dananya di CU, sehingga pembayaran balas jasa bunga simpanan anggota juga besar. 


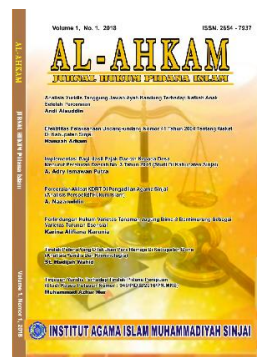

e) Beban penyusutan dan pemeliharaan asset yang tidak produktif yang menambah besar biaya yang harus dikeluarkan oleh CU.

f) Menurunnya pertumbuhan anggota dari tahun ke tahun.

4) Kerugian Akibat Kesengajaan dan Kelalaian Pengurus dalam Pengelolahan Credit Union

Pengurus yang diberi amanah dalam rapat anggota sebagai perpanjangan tangan anggota dalam mengurus dan mengelolah Credit Union tentunya memiliki tanggung jawab kerja yang harus dipertanggungjawabkan setiap tahunnya didalam rapat anggota. Tentunya didalam pertanggungjawaban tersebut ada penilaian tersendiri terhadap kinerja yang dihasilkan oleh seorang pengurus, terdapat batasan dan rambu-rambu yang harus diperhatikan oleh setiap pengurus didalam menjalankan tugasnya sebagai seorang pengurus Credit Union yakni adanya batas kewenangan seorang pengurus untuk dapat melakukan atau larangan untuk melakukan suatu perbuatan sesuai dengan aspek kepatuhan dan aspek kepatutan didalam tata laksana dan tata kelola yang baik suatu Credit Union. Adanya penyimpangan dari suatu aspek kepatuhan diluar dari batas kewenangan seorang pengurus, pastinya akan berdampak terhadap Credit Union itu sendiri, adanya beban kerugian yang akan dialami oleh Credit Union tersebut, baik materil maupun immateril.

Segala bentuk kerugian yang dialami sebuah Credit Union, tentunya akan menjadi beban dan tanggung jawab bagi seorang pengurus, baik itu secara bersama-sama maupun sendiri-sendiri untuk menanggung kerugian yang diderita, jika didalam penyelenggaraan tugas kepengurusan, pengurus terindikasi melakukan praktek kecurangan (froud) dan penyalahgunaan wewenang yang telah diberikan. Ada beberapa modus penyalahgunaan wewenang yang biasa terjadi dikalangan pengurus, yakni :

a) Nepotisme dan kronisme yang terjadi dikalangan pengurus, pengawas dan manajemen, sehingga sering memunculkan konflik kepentingan dan blok-blok internal yang berpengaruh kepada komunikasi yang tidak lancar, perbedaan sistem penggajian yang tidak sesuai dengan standar penggajian terhadap jabatan/posisi yang sama.

b) Penyalahgunaan dana yang berlebihan dan tidak tepat guna dan tepat sasaran, diperuntukan hanya untuk kepentingan pribadi. Misalnya penggunaan dana rapat dan pelatihan/training yang diselingi untuk traveling, hiburan dan liburan bersama keluarga.

c) Konsentrasi kekuasaan didalam kalangan pengurus dalam mengambil suatu keputusan, baik itu intervensi sesama pengurus maupun kepada manajemen.

d) Pemberian dan pengunaan fasilitas pinjaman yang tidak sesuai dengan aspek kepatuhan dan kepatutan, munculnya praktek-praktek pemberian kredit fiktif, pembiayaan yang berlebihan, nilai jaminan tidak sesuai dengan harga pasaran, penjamin dan jaminan tidak memenuhi kerangka ketuntuan yang berlaku, penghapusan pinjaman terhadap kredit yang bermasalah, pembaharuan pinjaman dan jaminan yang tidak sesuai 


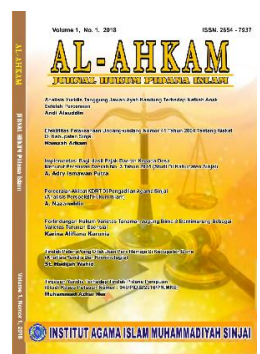

dengan ketentuan, tuntutan pemberian komisi atau fee atas pelepasan dan penjualan jaminan.

e) Akuntasi yang kreatif dan memalsukan informasi keuangan.

f) Pengeluaran biaya yang berlebihan untuk pemeliharaan atau pembelian aset-aset tertentu (bangunan, kendaraan alat tulis kantor dan lainnya)

g) Penjualan aset dibawah dari nilai kewajaran atau pasar.

h) Pembayaran deviden yang diperuntukan untuk provisi kredit lalai.

i) Bunga simpanan yang melebihi dari bunga pasar.

Keadaan tersebut semangkin diperburuk dengan kondisi tidak adanya keterbukaan (transpransi) dalam pelaporan pertanggungjawaban pengurus dalam setiap Rapat Anggota Tahun (RAT). Banyak permasalahan, peristiwa atau hal-hal tertentu yang terjadi ditutupi oleh pengurus kepada anggota. Misalnya kesalahan didalam mengambil suatu keputusan dan tindakan yang sifatnya menimbulkan kerugian bagi lembaga (Credit Union), baik tidakan tersebut dilakukan secara sengaja maupun karena kelalaian dari seorang pengurus maupun manajemen. Kejadian seperti inilah yang banyak menimbulkan pertanyaan sejauh mana kredibilitas seorang pengurus didalam mempertanggungjawabkan perbuatannya, tidak hanya pertanggungjawaban kepada anggota tetapi ada pertanggungjawaban secara khusus yang harus dipertanggungjawabkan dimata hukum berdasarkan peraturan perundangundangan yang berlaku.

Tanggung jawab atas kerugian yang dialami oleh sebuah Credit Union merupakan suatu kewajiban yang harus dipertanggungjawabkan oleh pengurus bila dikemudian hari terjadi tuntutan secara pidana (penyalahgunaan wewenang, penggelapan, penipuan dan pemalsuan) maupun gugatan secara keperdataan dari orang yang merasa dirugikan. Konsep pertanggungjawaban didalam hukum perdata dikenal dengan 2 (dua) istilah lilability without based on fault (pertanggungjawaban atas dasar kesalahan) dan lilability without fault (pertanggungjawaban tanpa kesalahan atau dasar resiko). Pada prinsipnya kedua bentuk pertanggungjawaban ini, memiliki arti bahwa seorang pengurus harus bertanggungjawab atas segala perbuatannya karena menimbulkan suatu kerugian terhadap orang lain terutama terhadap para anggota yang merupakan pemilik dari lembaga (Credit Union) tersebut. Pertanggungjawaban pengurus tersebut pada dasarnya telah melakukan suatu perbuatan sebagai mana yang dimaksud dialam pasal 1365 KUHperdata, adanya kesalahan (kelalaian) dalam suatu perbuatan yang menimbulkan kerugian terhadap orang lain yang menimbulkan sebab akibat (hubungan kausalitas (Clara Yunita Ina Ola. 2017 : 134-146).

Tebal 5

Analisa Perkembangan Kredit

\begin{tabular}{|c|c|c|c|c|c|}
\hline $\begin{array}{c}\text { Tahun } \\
\text { Buku }\end{array}$ & $\begin{array}{c}\text { Jumlah Hutang } \\
\text { Beredar }\end{array}$ & Kredit Lalai & Rasio & Ideal & SHU \\
\hline 2016 & 25.722 .121 .631 & 3.538 .395 .550 & $13.76 \%$ & & -148.695 .805 \\
\hline 2017 & 26.114 .094 .000 & 5.050 .169 .000 & $19.34 \%$ & $\leq 5 \%$ & -228.790 .163 \\
\hline 2018 & 25.301 .799 .900 & 4.162 .817 .848 & $16.45 \%$ & & +115.692 .702 \\
\hline
\end{tabular}




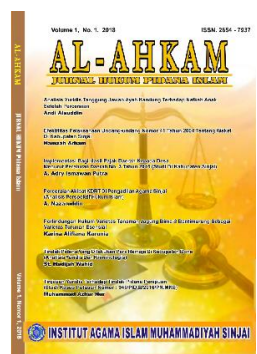

\begin{tabular}{|l|l|l|l|l|l|}
\hline 2019 & 23.427 .078 .905 & 6.008 .723 .350 & $25.65 \%$ & & -111.343 .223 \\
\hline 2020 & 19.912 .995 .699 & 5.241 .212 .300 & $26.32 \%$ & & -351.109 .584 \\
\hline
\end{tabular}

Sumber Data : KSP. CU Muare Pesisir

Pemberian pinjaman yang tidak teratur akan dihadapkan dengan meningkatnya pinjaman lalai yang tidak dapat tertangani, yang disebabkan oleh :

a) Anggota kurang bertanggungjawab terhadap pengembalian pinjaman sehingga menimbulkan pinjaman kredit menjadi macet.

b) Usaha yang dijalani anggota menurun.

c) Pinjaman yang diberikan melebih dari kemampuan membayar.

d) Jaminan tidak dapat dieksekusi karena tidak memenuhi legal proper.

e) Anggota terlibat permasalahan hukum.

f) Pembayaran tidak tepat waktu dan tepat jumlah

g) Hanya membayar bunga pinjaman sampai dengan jatuh tempoh kredit pinjaman kredit tidak dilunasi.

h) Pinjaman tidak ditagih

Selain itu dampak terjadinya pinjaman lalai anggota terhadap perkembangan dan keberlanjutan CU, adalah sebagai berikut :

a) Semangkin tinggi pinjaman lalai maka likuiditas akan semangkin rendah.

b) Menurunya kemampuan penyediaan pinjaman, sehingga pendistribusian kredit semangkin rendah kepada anggota.

c) Menurunya pendapatan yang akan berpenngaruh kepada SHU (sisa hasil usaha)

d) Rendahnya kemampuan CU untuk menutupi biaya operasional

e) Kemungkinan besar apabila tidak tertangani dengan segera $\mathrm{CU}$ tersebut dapat mengalami kebangrutan.

4. Simpulan

Kewenangan dan tanggung jawab yang diberikan oleh pengurus didalam sebuah Credit Union merupakan mandat yang diberikan oleh anggota untuk mengatur, mengurus dan mengelolah segala usaha yang dijalankan oleh Credit Union tersebut. Didalam kewenangan dan tanggungjawab tentunya memberikan hak dan kewajiban yang harus dilakukan oleh pengurus selama menjabat, disamping itu juga terdapat batasan yang harus dipatuhi oleh setiap pengurus, karena terdapat konsekuensi yang harus dipertanggungjawabkan baik secara sendiri-sendiri maupun bersama-sama jika mengakibatkan suatu kerugian bagi lembaga. Pertanggungjawab pengurus KSP. CU Muare Pesisir wajib dilaporkan kepada anggota secara berkala (perbulan, tiga bulan, enam bulan dan satu tahun) yang wajib disahkan oleh anggota didalam Rapat Anggota Tahunan. Laporan pertanggunggjawab tersebut mencakup keorganisasian lembaga, pertumbuhan dan perkembangan anggota, dan keuangan lembaga.

Timbulnya kerugian yang derita oleh KSP. CU Muare Peisisr disebabkan karena tingginya angka pinjaman lalai yang tidak tertanggihkan dan tidak dapat terselesaikan, dikarenakan tidak terpenuhi syarat administari, analisa kredit yang tidak memadai tidak sesuai dengan asas kepatutan dan patuhan tanpa intervensi dari 


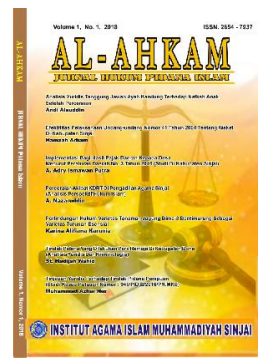

pihak manapun, kredit fiktif dan tidak terpenuhinya legal proper didalam pemberian pinjaman, sehingga lemahnya kedudukan lembaga pada saat mau melakukan eksekusi didalam penyelesaian pinjaman lalai. Selain itu terdapat penyimpangan didalam penggunaan dana yang dipergunakan untuk kepentingan dan keuntungan pribadi. Rapat Anggota Tahunan dapat meminta petanggunjawaban pengurus terhadap kerugian yang diderita baik secara sendiri-sendiri maupun secara bersamasama yang karena kesengajaan dan kelalaian pengurus selama mengurus dan mengelolah CU, untuk dikembalikan kepada lembaga yang dapat diajukan melalui gugatan perdata maupun tuntutan pidana (penggelapan, penipuan dan pemalsuan)

\section{Daftar Pustaka}

Abdulkadir Muhammad (2004). Hukum dan Penelitian Hukum. Bandung : Citra Aditya Bakti.

Frans Laten, Serapina Serapin. (2017). Modul Pendidikan dan Pelatihan Analisis Kredit dan Penanganan Kredit Lalai. Pontianak : Pusat Koperasi Kredit BKCU Kalimantan

Herkulanus Cale, Frans Laten, Serapina Serapin. (2017). Modul Pendidikan dan Pelatihan CUCCC (Credit Union Ceo's Competency Cource). Pontianak : Pusat Koperasi Kredit BKCU Kalimantan

J.G. Brouwer dan Schilder. 1998. A Survey of Dutch Administrative Law. Nijmegen : Ars Aeguilibri.

Munaldus, Yuspita Karlena, Yohanes RJ, Saniansah, B. Hendi. (2012). Credit Union Kendaraan Menuju Kemakmuran Praktek Bisnis Sosial Model Indonesia. Jakarta : PT. Elex Media Kompurindo

Nur Basuki Winarno. 2008. Penyalahgunaan Wewenang dan Tindak Pidana Korupsi. Yogjakarta : Laksbang Mediatama.

Soerjono Soekanto. (2006). Penelitian Hukum Normatif. Jakarta : PT Raja Grafindo Peresada.

Sukoco Irianto. (2017). Modul Pendidikan dan Pelatihan Tata Kelola Credit Union. Pontianak : Pusat Koperasi Kredit BKCU Kalimantan

\section{Jurnal :}

Emmons, William R.; Schmid, Frank A. (1998) : Credit Unions and the common bond, CFS Working Paper, No. 1999/01, Goethe University Frankfurt, Center for Financial Studies (CFS), Frankfurt a. M.,(pp. 1-2)

Martono. (2016). Analisis Pengaruh Efiseinsi Modal Kerja Terhadap Profitabilitas Pada Credit Union Pancur Kasih Pontianak. Diakses dari https://ldikti11.ristekdikti.go.id/jurnal/pdf/d32483e8-3092-11e8-9030-54271eb90d3b/

Nicodemus Simu. (2017). Analisis PEARLS : Ukuran Tingkat Kesehatan Koperasi Kredit (Credit Union). Diakses dari https://dosen.perbanas.id/analisis-pearls-ukuran-tingkatkesehatan-koperasi-kredit-credit-union/

\section{Undang-undang}

Undang-undang Nomor 25 Tahun 1992 tentang Perekonomian 